\title{
Regulatory Elements on the Circular Economy: Driving into the Agri-Food System
}

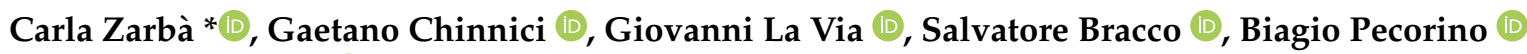 \\ and Mario D'Amico (D)
}

check for updates

Citation: Zarbà, C.; Chinnici, G.; La Via, G.; Bracco, S.; Pecorino, B.;

D'Amico, M. Regulatory Elements on the Circular Economy: Driving into the Agri-Food System. Sustainability 2021, 13, 8350. https://doi.org/ $10.3390 /$ su13158350

Academic Editor: Antonio Boggia

Received: 30 June 2021

Accepted: 16 July 2021

Published: 27 July 2021

Publisher's Note: MDPI stays neutral with regard to jurisdictional claims in published maps and institutional affiliations.

Copyright: (C) 2021 by the authors. Licensee MDPI, Basel, Switzerland. This article is an open access article distributed under the terms and conditions of the Creative Commons Attribution (CC BY) license (https:// creativecommons.org/licenses/by/ $4.0 /)$.
Department of Agricultural, Food and Environmental (Di3A), University of Catania, Via S. Sofia No. 98-100, 95123 Catania, Italy; chinnici@unict.it (G.C.); giovanni.lavia@unict.it (G.L.V.); salvatore.bracco@unict.it (S.B.); pecorino@unict.it (B.P.); mario.damico@unict.it (M.D.)

* Correspondence: carlazarba@hotmail.it

Abstract: In the transition from linear production systems, unsustainable from the point of view of resources, to a model that finds strength in environmental, social and economic sustainability, the circular economy paradigm is the foundation that facilitates the planetary agro-ecological transition. The European Union has taken a number of steps (including the Circular Economy Package of Directives) shaping circularity as a wide-ranging driver measure involving many sectors. The paper intends to provide a regulatory framework on the current general situation regarding circularity in European Union, in order to extrapolate and give evidence to the aspects that intersect the agri-food sector. This is not only because they are poorly addressed in the literature, but also because there is a lack of regulatory instruments on the circular economy specifically addressing this area of interest. For this purpose, the analysis focuses on waste and residue/scrap management issues, recognized by law as by-products and end-of-waste status, as they are covered by circular economy legislation and as they can be applied to the agri-food sector. The latter allow the implementation of circularity strategies in the agri-food sector and, given the numerousness of production chains and the peculiarities of each of them, various regeneration and/or reuse processes of specific resources may be depicted. The intent is to provide useful knowledge on how to implement sustainable waste management, also proposing a concrete case on a by-product of olive oil processing, through which it is possible to highlight how the correct application of regulations favors the adoption of circular economic and management models in the firms involved, as well as informing the relevant economic operators on the possible profiles of legal liability that may arise from insufficient knowledge. Furthermore, this paper delves into the European Green Deal's Strategy as it enriches the circular economy paradigm with new facets. NextGenerationEU and the National Recovery and Resilience Plan financially support this strategy in the aftermath of the socioeconomic crisis from COVID-19 in the EU Member States. This is in order to achieve the objective of achieving the agro-ecological transition.

Keywords: regulatory elements; circular economy; agri-food; olive oil sector

\section{Introduction}

In the last decade, the circular economy has become one of the main priorities of European Union policies, and it has become a new paradigm that tends to reduce natural origin resources withdrawal and make their reuse profitable. In brief, that is a model of production and consumption [1] that extends the life cycle of products, reducing waste to a minimum.

In the past, issues [2] such as resource scarcity and environmental pollution were underestimated in their threatening nature on a global scale, whereas, nowadays, they are assessed and supported through the lens of the circular economy. Those issues have quickly proven to be emergencies [3,4], becoming fundamental objectives of policymaking, aimed at finding possible solutions even about the growing world population. The growth 
trend, "approximately 83 million people each year" [5], has shown the need to decrease the overexploitation of primary resources in a sustainable perspective, as resources are scarce and finite [6]. "By 2050 it is projected to reach 9.8 billion people, more than two-thirds of whom will live in cities" [5].

The persistence and the overflow [7] of these important issues highlighted the ineffectiveness of those previous approaches and showed the urgency of depicting, in response to them, a new concept. The expectation was, on the one hand, that this new concept would be more incisive, so as to abandon abstractions and generalities, and, on the other hand, that it would have taken into account the elements of interconnection [8] existing between these issues, so as to enhance the interdependence between them. All this has led institutions to intervene in several topics. On the conservation and/or preservation of natural ecosystems and on the efficient use of resources (with a view to the development of renewable energies), on the use of raw materials derived from plants, on scraps (establishing their use as raw material for new products) and on minimizing the level of waste to reduce the environmental pollution [9].

The waste management issue is not reassuring [10], in the European Union, the quantity produced is not decreasing, and in the meantime, waste reduction targets are set for specific waste streams under the banner of prevention [11] or because of their re-use and recycling.

In particular, in the agri-food sector, given the number of production chains and the specific peculiarities of each of them, numerous activities emerge in which scraps, residues and wastes may be managed as assets [12] and, therefore, potentially become a resource. Thus, scraps, residues and wastes may encounter a new life, through re-use systems, in another production chain, even different from the one for which they were generated $[13,14]$. All this determines undeniable advantages both for the environment and for the economic benefits of firms that implement processes for the reduction of waste (upstream) and for the recovery of waste with residual utility for the appropriate specific activities of reuse and/or recycling (downstream). Therefore, also in the agri-food sector, when scraps/residues and waste meet all the conditions provided by the reference legislation in force, they may be considered by-products with end-of-waste status.

The regulatory perspective is preliminary to the highlighting of economic and management issues within one of the segments of food processing in Italy.

It is relevant to note that the European legislation and implementing measures in Italy on the circularity are not directly related to the agri-food sector; hence, the analysis has to necessarily start from the general context and then derive the applications related to the agri-food sector.

For this purpose, the present paper intends to provide, without any claim to be exhaustive, a regulatory framework on the current general situation regarding circularity in European Union in order to extrapolate and give evidence to the aspects that intersect the agri-food sector. This is done not only because those aspects have been poorly explored in the literature, but also because there is a lack of circular economy regulatory instruments addressed specifically to this area of interest. Moreover, the analysis delves into waste and residue/scrap management issues, recognized by law as "by-products" and having "end-of-waste status", as they are covered by circular economy legislation and as they can be applied to the agri-food sector.

Therefore, the research aims to inform about the possible legal liability profiles that economic operators may face as a result of insufficient knowledge, as well as to involve them in the application of circular management models in the agri-food sector. To this end, the paper also provides the example of a case law on an olive oil sector by-product, which leads to some considerations of an economic-management and environmental management nature.

This is in the hope that such an in-depth study will, on the one hand, act as a starting point for concrete initiatives that are similar to the circular models and, on the other hand, that it can offer interpretative hints to avoid incurring legal responsibilities. Alongside the 
regulatory aspects, economic and collective issues arise, highlighting the paradigm shift towards the transition from a linear to a circular production model that may result from the application of the other circular economy directives.

Finally, the European Green Deal's strategy and the subsequent instruments NextGenerationEU [15] and National Recovery and Resilience Plan (NRRP) [16] are also discussed as they give new contours to the content of circularity and supports. In particular, the latter two instruments emerged in the aftermath of the socio-economic crisis from Covid19 in the EU Member States to achieve the goal of facilitating agro-ecological transition in the new global context.

\section{Methodology}

The present analysis proposes the results of a study on regulatory sources and documents of the European Union in support of the circular economy and its implementation in Italy [17]. This is done in order to highlight and analyze elements that can be applied to the agri-food sector, considering that there are no regulatory instruments on circular economy directly addressed to this sector. Such circumstances involve economic and management problems for the firms involved. Combining these latter elements with legal ones has led to the use of an interdisciplinary research approach which combines different disciplines [18].

In fact, European and Italian legislation, in the field of circular economy, has been examined to identify issues related to the agri-food sector, allowing to highlight the economic and management implications of the parties involved. Hence, the use of a qualitative method, such as the case law study, led to illustrating how the proper application of byproduct legislation avoids to incur criminal liability and avoid environmental impacts. In particular, the paper is structured starting from a brief overview of the steps taken by scholars and thought leaders to define the concept of the circular economy. Then the research expands on the analysis of the documents and normative acts of the European Union and of Italy, foregrounding aspects of interest for the agri-food sector, so as to highlight the importance of having a specific legislative framework $[19,20]$.

Then, the exploration of by-products and end-of-waste status issues, and the analysis of a case law inherent to the agri-food sector, allowed to highlight how the compliance with the principles and regulatory conditions by the agri-food operators have implications of economic management nature on firms, as well as of global environmental management nature. Finally, recent European documents that enrich with new facets the circular economy paradigm have been examined, taking also into account the scenario determined by COVID-19.

\section{Towards the European Union Circular Economy Package}

\subsection{Driving the Circular Economy Concept}

The first attempts to abstract the concept of circular economy cannot be ascribed to a single [21] author or school of thought, but to the impulses of different scholars and thought leaders, starting from the late 1960s [22], which were accompanied and followed, shortly thereafter, by the first practical applications in economic realities.

Indeed, before the term circular economy came to light, numerous studies and research were developed around the world related to ecological, environmental, social, etc., issues and/or phenomena that can be traced back to the circular economy paradigm. The following is a brief recognition of some of the events through the years, as outlined in Figure 1.

In 1965, Adlai Stevenson [22], during a United Nations Assembly, stated that "air and soil are vulnerable reserves". In 1966, Kennett Boulding, economist and philosopher of the evolution of natural systems, spoke about scarcity of resources [23], while Boulding and Jarrett spoke of "seemingly unlimited resources and the threat of pollution", glimpsing that survival is linked to a cyclical ecological system [23,24]. He also wrote in an essay on "Spaceship Earth" about the "economy as a circular resource flow system" [25,26]. In 1970, John T. Lyle, a U.S. college professor, discussed "environmental degradation, renewable resources, 
and regenerative design" [27], setting a precedent that formed the inspiring basis for the opening of a research center in California eventually named after him. In 1971, Barry Commoner, a biologist in the United States of America, published the book The Closing Circle, in which he argues that in the biological world "there is no waste because everything is returned to nature as a resource" [28].

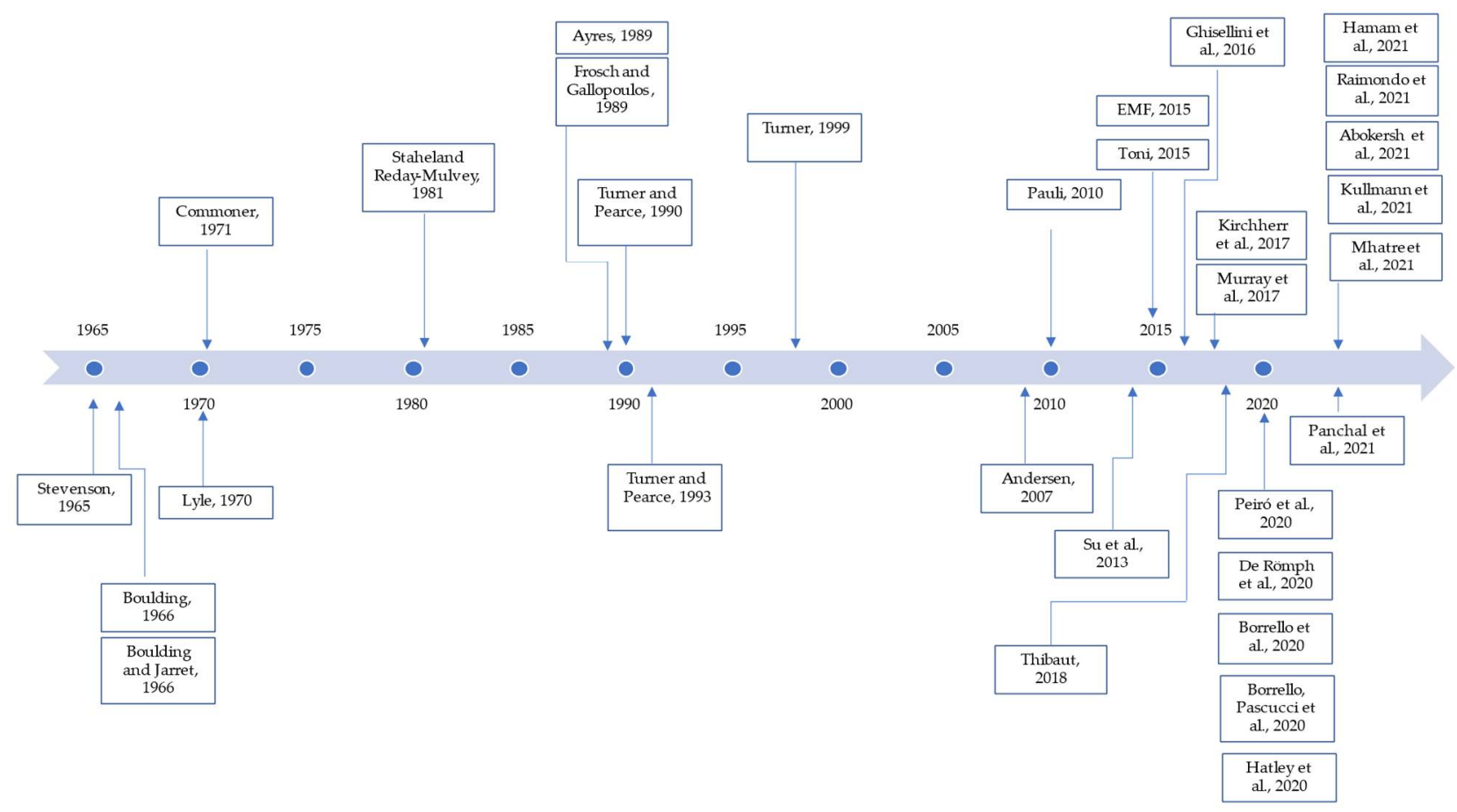

Figure 1. Circular Economy Concept Flow.

In 1976, Walter Stahel and Reday-Mulvey, in a research report to the European Commission in 1976 (later published in 1981) [29], express a vision of a loop economy [30] and the impact it would have on the creation of new employment, on economic competitiveness, on the saving of resources and on the upstream reduction of waste production. In the late 1980s, Ayres, Frosch and Gallopoulos underlined in their research the relevance of "cloosing the loops in industrial process" [31,32]. In 1990, Turner and Pearce in a study on the ethics of sustainable development based on the work of Kennet Boulding, underlined the connection between economy and environment and they used the expression "circular economy" [33,34]. Several authors [35] in their writings ascribe the creation of the concept of circular economy to Pearce.

In the years that followed, the dialogue gradually took on a more specific focus, leading in the first decade of the current millennium to the notion of a self-regenerating economy (Blue economy) [36].

Another part of the scientific literature [37-39] indicated that "circular economy origins are mainly rooted in ecological and environmental economics and in industrial ecology" [1,21].

In the panorama of defining the circular economy concept, the Ellen Mc Arthur Foundation plays an eminent role; it develops and promotes the idea that "circular business opportunities are mainly hindered by non-financial barriers and suggests that a sector by sector approach would be the most appropriate to identify the most relevant opportunities, barriers and policy options" [40].

A point of reference in the literature is the study by Kirchherr et al. [41], who, based on the previous 114 definitions [42], outline the boundaries of the concept of the circular economy; in fact, subsequent studies indicate it and then focus on specific topics such as "energy systems" [43,44], "sustainable development" [45-49], operational definitions [50]. 
Over the years, therefore, efforts have been focused on creating a general theory that would coordinate the various economic, environmental, social, etc., issues homogeneously in order to include and amalgamate them under a single theoretical framework to preserve the planet from potentially irreversible damage. However, for a long time, there has been a lack of codification at the regulatory level to fulfil the intention to adjust the economic and social system to the needs of the planet. Indeed, European institutions have been slow to grasp the urgency of intervening to make economic models compatible to safeguard ecosystems.

The challenge was certainly not an easy one; on the one hand, it appeared necessary to intervene in a more specific and stringent way than the general environmental regulations in force. On the other hand, the aim was to formulate a brand new concept that would be both comprehensive and transversal, thus including and coordinating different related issues and not only environmental ones.

The significance of the precursors' thoughts and analyses on the circular economy is evident from the fact that they are still relevant today. However, their topicality leads to reflect on the fact that the advancement towards the circular transition may still be lagging. These thoughts and analyses may therefore still serve as points of reference for political institutions responsible for formulating integrated regulatory systems that are above all instrumental in solving concrete problems [39].

\subsection{Political and Regulatory Framework in the EU}

The propulsive thrusts towards the theoretical framing of certain practical issues around eco-sustainable and environmental themes made it clear that there was an expectation of an institutional response to express them formulaically.

In the last decade, European institutions have attempted to develop, in increasing detail, strategies based on sustainable economic models, starting from the explication of the importance of recognizing, politically and legislatively, the link between environment and economy, "boosting economic performance while reducing resource use" [51], explicitly defining the concept of circular economy [52], developing ad hoc measures [53] and finally including this concept in legislation with a rationalization of an ad hoc framework (package of Directives on circular economy), as shown in Figure 2.

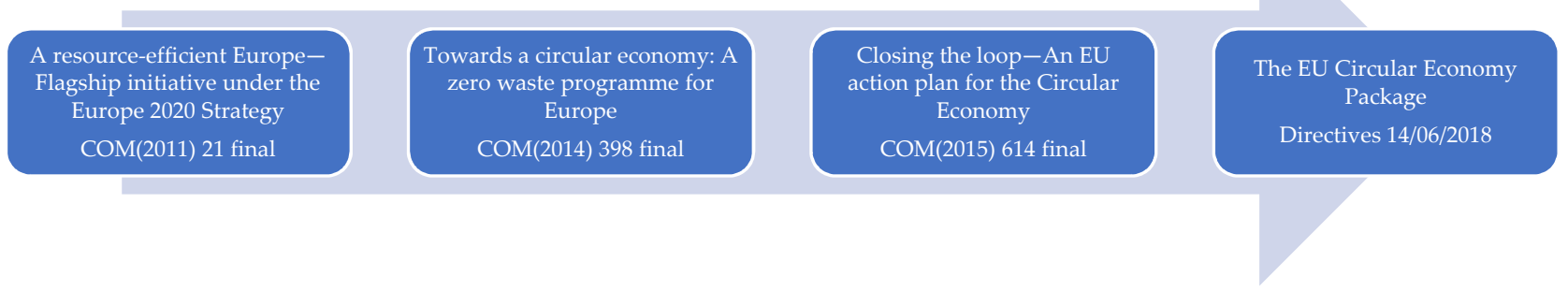

Figure 2. Regulatory and Policy Flow on Circular Economy in the European Union.

In particular, with the Communication "Towards a circular economy: A zero waste programme for Europe" [52], the European Commission places the circular economy at the center of the resource efficiency agenda set out in the Europe 2020 strategy for smart, sustainable and inclusive growth: the "circular economy preserves the value added in products for as long as possible and virtually eliminates waste".

With the proposed actions, the Communication officially makes the circular economy the key paradigm of any strategy that globally and transversally covers many sectors. Given the economic, social, cultural and structural importance of the circular economy, it is set that supporting measures are financially sustained (such as "European Structural and Investment Funds"-ESIF, "Horizon 2020" [54], "European fund for strategic investments"-EFSI and "LIFE Programme" [55]). 
The question of the interdependence of the value chain's processes for certain sectors prevails. In the past, most sectors were considered as separate, while now they are seen as interconnected. Some examples are the extraction of raw materials and product design, the production, the distribution, the consumption, the reuse and the recycling of materials ("the Commission will examine options and actions for a more coherent policy framework for the different strands of work on EU product policy in their contribution to the circular economy") [53], biomass, organic, etc. [56]. The Commission also aims to make consumers aware of environmental aspects. In this way, the result may be to orient them towards sustainable and circular choices, so as to prefer to purchase renewable or recycled products (the role of the consumer is also considered fundamental in the case of choosing), among homogeneous products, those that have green labels, the EU Ecolabel, etc. [57].

Among the main strategies of the Communication "Closing the loop", there is the expectation of creating a connection between resource efficiency and rational waste management. In particular, it concerns production scraps or processing residues that may be used as an asset. The fulfilment of these projects would make it possible to avoid extracting new natural resources and not undermine their scarcity. All this may bring economic, social and environmental benefits. In this case, the linear representation where the efficient use of resources comes before rational waste management becomes closed, circular, and this is precisely the vision of the Commission behind the expression "Closing the loop".

The novelty of the initiatives and measures foreseen by "Closing the loop" Communication led to the revision of the existing European directives on waste management [58] and based on the linear model. Thus, in order to promote the transition to a new circular economic model, the European Parliament, at its plenary session on 18 April 2018, approved the directives of the so-called "circular economy package". Starting from the general objectives of the Commission's Communications (2014-2015) on the Circular Economy, the European institutions enact four directives that intervene in specific sectors. Among these the agri-food sector is not included and for this reason this paper proceeds to extrapolate, from the given directives, the topics of interest that concern the agri-food sector.

Table 1 shows EU Circular Economy Package's Directives and in particular the Directive (EU) 2018/849 results consistent with the circular economy paradigm's principles and objectives. The modifications tighten up the management and information obligations previously laid down and set some rules [59] to be able to effectively monitor the adoption of the system established by the waste hierarchy, in relation to these types of products. Directive (EU) 2018/850/UE aims to progressively reduce landfilling of waste, in line with the principles of implementing the circular economy. It also reinforces the targets by setting more restrictions on landfilling and encourage recycling and recovery operations.

Table 1. The EU Circular Economy Package-Directives.

\begin{tabular}{|c|c|c|}
\hline Directive No. & Date & $\begin{array}{l}\text { Official Journal of the } \\
\text { European Union }\end{array}$ \\
\hline $\begin{array}{l}\text { Directive (EU) 2018/849 } \\
\text { amending Directive } \\
\text { 2000/53/EC on end-of-life vehicles, 2006/66/EC on } \\
\text { batteries and accumulators and waste batteries and } \\
\text { accumulators, and 2012/19/EU on waste electrical } \\
\text { and electronic equipment }\end{array}$ & 30 May 2018 & L 150, 14.6.2018 \\
\hline $\begin{array}{l}\text { Directive (EU) } 2018 / 850 \\
\text { amending Directive } \\
\text { 1999/31/EC on the landfill of waste }\end{array}$ & 30 May 2018 & L 150, 14.6.2018 \\
\hline $\begin{array}{l}\text { Directive (EU) } 2018 / 851 \\
\text { amending Directive } \\
\text { 2008/98/EC on waste }\end{array}$ & 30 May 2018 & L 150, 14.6.2018 \\
\hline $\begin{array}{l}\text { Directive (EU) 2018/852 } \\
\text { amending Directive } 94 / 62 / \mathrm{EC} \\
\text { on packaging and packaging waste }\end{array}$ & 30 May 2018 & L 150, 14.6.2018 \\
\hline
\end{tabular}


Directive (EU) 2018/851 is the "framework directive", among the four directives of the circular economy package, as it makes explicit the "waste hierarchy", which also applies to the other three directives. Under the general core principle of the "waste hierarchy", prevention is a central pivot and is supported by provisions on "extended producer responsibility". In this context, with the intent to guide the Member States towards a European circular economy with a high level of resource efficiency, the Directive also introduces and amends several definitions of waste and clarifies the definitions of "by-product" and "end-of-waste status".

In light of the above considerations, Directive 2018/851/EU requires the Member States to adopt prevention programs to be included in waste management plans or environmental policy programs: to develop safe recovery and disposal operations; to put in place a system for quality control, traceability, waste calculation and verification of the achievement of waste prevention targets.

Waste reduction targets are also quantified. To support the obligations to be met, it is envisaged that the Commission will develop information/announcement tools for communication with the Member States. Waste reduction targets are also quantified. The Directive also foresees that the Commission will develop information/announcement tools for communication with the Member States to support them in meeting their obligations.

Finally, Directive (EU) 2018/852 introduces new definitions of packaging waste, reusable packaging and composite packaging, and establishes general criteria for the design, production and marketing of packaging. Given the new recovery and recycling targets it requires the Member States to set up quality control and traceability system for packaging waste and to report to the European Commission about it, for effective and rapid implementation. In this context, the focus on the quality of biodegradable packaging waste materials that can be included in the calculation of the quantitative level of recovery and recycling is not only innovative but relevant for the agri-food sector. In particular, it is foreseen that "the amount of biodegradable packaging waste that enters aerobic or anaerobic treatment may be counted as recycled where that treatment generates compost, digestate, or other output with a similar quantity of recycled content in relation to input, which is to be used as a recycled product, material or substance. Where the output is used on land, Member States may count it as recycled only if this use results in benefits to agriculture or ecological improvement".

\section{The Implementation of Circular Economy Package in Italy}

\subsection{Political and Regulatory Framework}

The implementation in Italy of the "circular economy package" has taken place through the four Legislative Decrees indicated below that trace the four EU Directives' path (Figure 3).

Legislative Decree no. 116/2020 amends Part IV of Legislative Decree no. 152/2006, the "Consolidated Environmental Act" (or "Environmental Code") in order to implement Directive 851/2018/EU, about waste management, and Directive 852/2018/EU, concerning packaging.

Regarding the packaging issues, a central function of the Legislative Decree no. 116/2020 was to strengthen the National Waste Prevention Program established in Italy in 2013 by Directorial Decree of 7 October 2013, the Ministry of the Environment and Protection of Land and Sea to support measures related to the prevention of waste dispersion in the natural environment and the reduction of waste of food. The "Ministry of the Environment and Protection of Territory and Sea" and the "Ministry of Agricultural Food and Forestry Policies" together with the Regions play a key role in encouraging the recycling of organic waste and giving priority to other ways of managing organic waste, thus, encouraging recovery chains, waste reduction and material recycling. In this respect, the role of the regions aims to help develop the agro-ecological model, which seeks to reconnect producers and consumers through a circular and solidarity-based economy to favor local markets and supports territorial development $[60,61]$. 


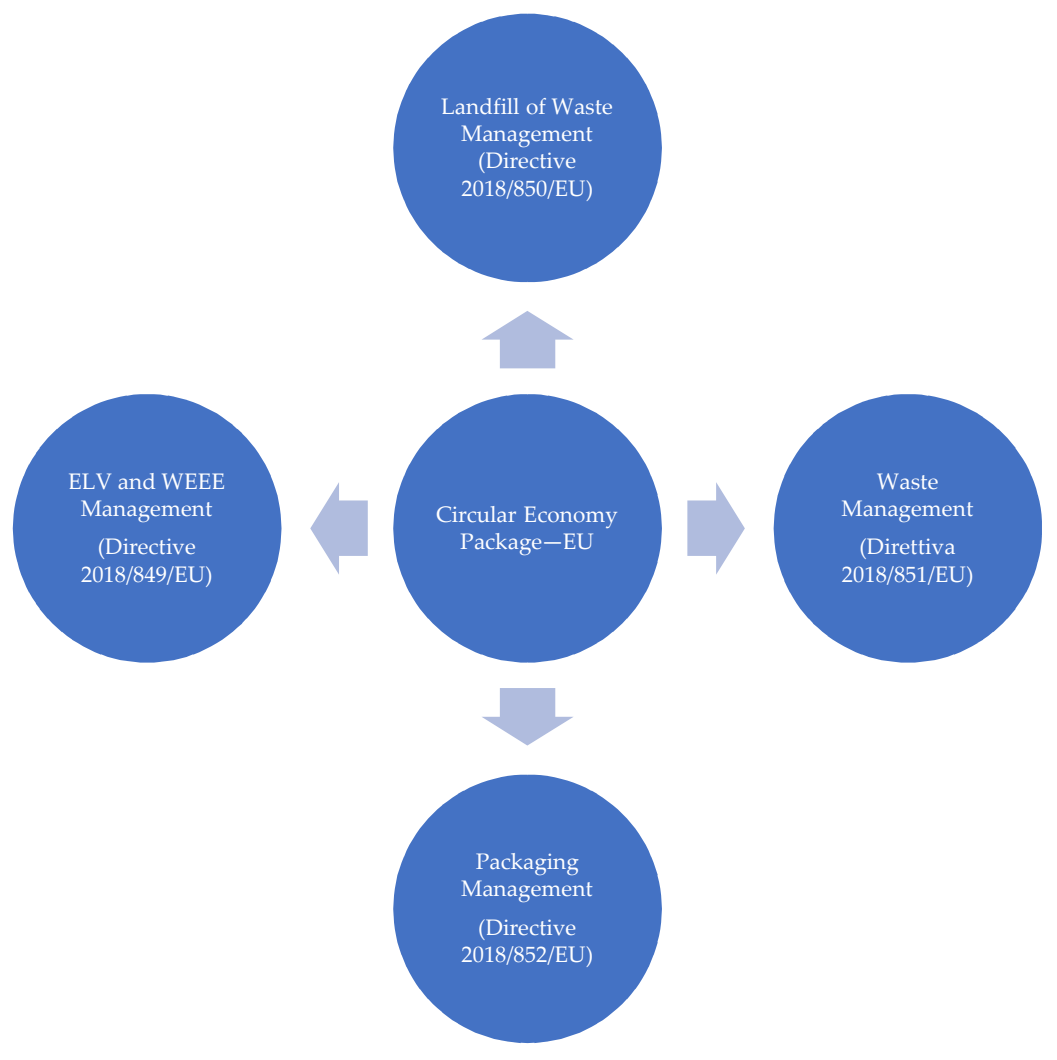

(a)

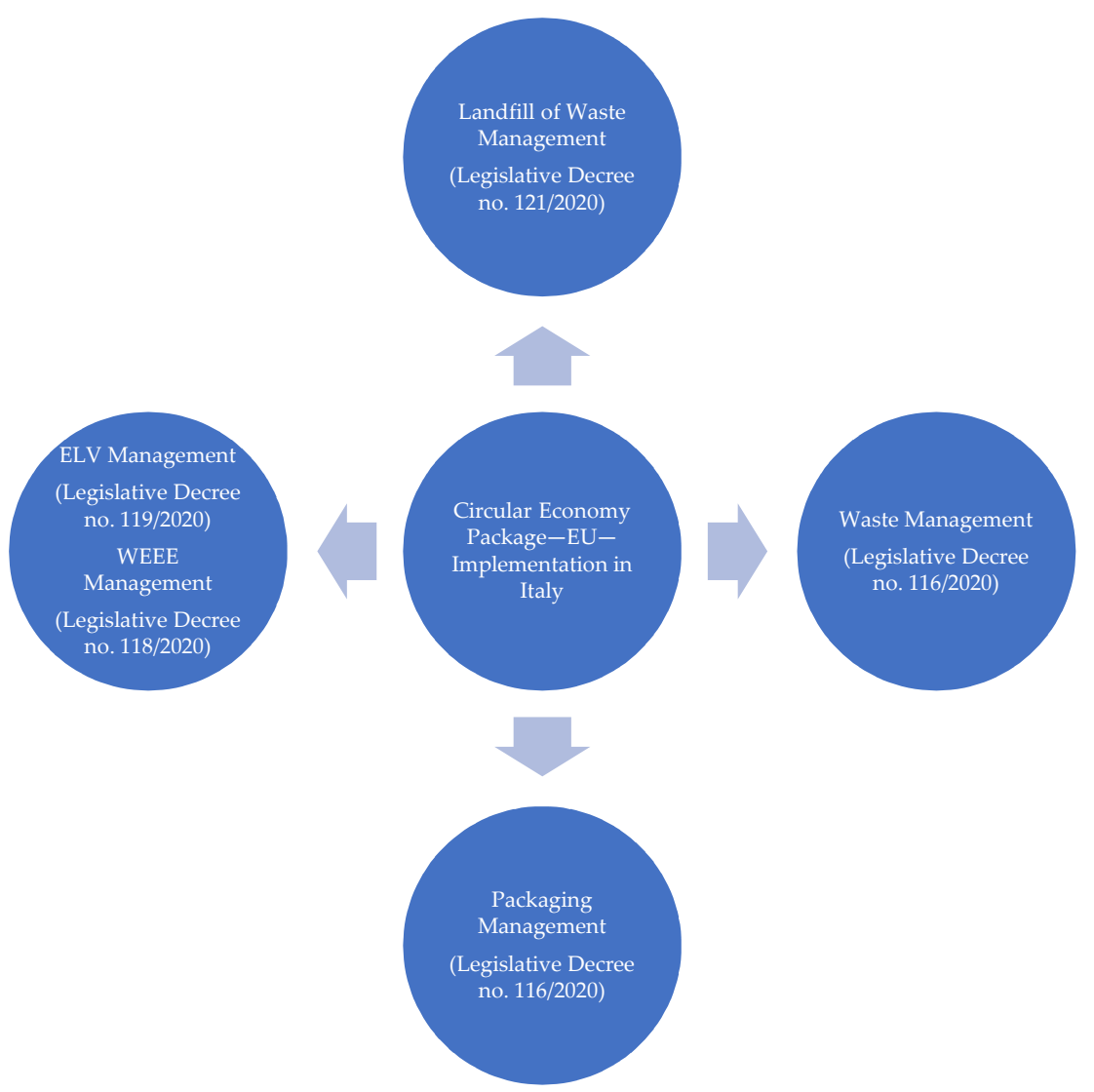

(b)

Figure 3. Circular Economy Package in EU (a) EU Directives and in Italy (b) Legislative Decrees. 
Relevant to activities related to the agri-food sector is also the inclusion of the definition of "composite packaging" (for the objectives of recovery and recycling of packaging), the incentive for recycling to prevent waste production, as well as industrial symbiosis and other forms of recovery.

Concerning waste management, the unsustainable level of waste of materials, products or substances, in the past, could have induced producers to adopt alternatives to disposal to exploit them as possible resources. For a long time, the problem has persisted because those who often produced waste did not directly face and bear the related costs. This was not a very coherent system, since sustainable management of materials, products or substances may be more accessible for those who directly produce them. In this context, the Legislative Decree no. 116/2020 establishes the principle that the cost of pollution must be borne by those who produce the polluting good. This novelty implies that those who produce wastes would find it convenient not to generate them; indeed, the "Extended Producer Responsibility" (EPR) system has now been introduced "to ensure that producers [62] of products bear financial responsibility or financial and organizational responsibility for the management of the waste stage of a product life cycle". This legal arrangement plays a key role in preventing waste production and encouraging producers to extend the life cycle of products and materials.

To monitor the compliance with the obligations of extended producer responsibility, Legislative Decree no. 116/2020 establishes new mechanisms of traceability through the "National Register of Producers", indicating the procedures for filling in loading and unloading and the list of obliged and exempted subjects. All of this is also at the service of the valorization of production waste and recoverable waste within the framework of the waste hierarchy.

A desired perspective seems to concern the change in approach towards greater communication between the various segments of the supply chain. All this is done in order to make operators overcome the compartmentalized view by encouraging [63] greater trust between the various figures along the supply chain. In concrete terms, enabling a greater exchange of information between operators effective would ensure that waste holders would be correctly informed about prevention measures; producers can guarantee the correct information to users of their product and waste holders.

Moving on to Legislative Decree no. 121/2020, regarding landfills, it amends Legislative Decree no. 36/2003 and contains measures aimed at progressively reducing the landfilling of waste, especially those wastes suitable for recycling and recovery; this takes into account the relevant provisions of the already mentioned Legislative Decree no. $152 / 2006$ and subsequent amendments and additions. It also repeals the Ministerial Decree of 27 September 2010, but the limits set out in Table 5, (a), of Article 6 continue to apply until 1 January 2024.

It also establishes operational and technical requirements for waste and landfills, measures, procedures and guidelines aimed at preventing or reducing as much as possible the negative impact on the environment. In particular, it amends Decree of the Ministry of the Environment of 27 September 2010, Legislative Decree No. 36 of 13 January 2003, and ISPRA Guidelines of 7 December 2016, No. 145). It also repeals the Ministerial Order of 27 September 2010, with the exception that the limits in Table 5, note (a), of Article 6 continue to apply until 1 January 2024.

The decree pursues a comprehensive reorganization of landfill eligibility criteria; the basic specification of each type of waste delivered to landfills, and compliance criteria, taking into account technological progress. Moreover, the Legislative Decree recognizes and emphasizes the importance of the role of the Regions and Autonomous Provinces in a perspective of coordination with the state bodies to make its application effective.

Regarding the other legislative decrees mentioned above, only measures that involve the agri-food sector are highlighted here, albeit in a limited number.

Thus, Legislative Decree no. 118/2020 amends Legislative Decree 188/2008 and Legislative Decree 49/2014 (implementing, respectively, Directives 2006/66/EC on batter- 
ies and accumulators and waste batteries and accumulators and 2012/19/EU on waste electrical and electronic equipment (WEEE).

The decree introduces a rationalization of the WEEE provisions for photovoltaic, establishing that "the financing of the management of WEEE arising from photovoltaic EEE is the responsibility of producers regardless of the date of placing on the market of such equipment and whether it is of domestic or professional origin [ ... ] without prejudice to the financial guarantee instruments activated by producers".

These provisions on renewable energy production systems from photovoltaics may have an important impact on the agri-food sector, where there is room for sustainable business management models. In fact, the processing lines of the supply chains have various functions such as processing, transformation, packaging and packaging, etc. and remain active for production for many hours a day. These systems use electricity, resulting in a huge cost for firms. Setting up firms' plants so that they can use renewable energy through photovoltaics would lighten the burden of electricity costs and, at the same time, would avoid high consumption, thus participating in the circular objectives that tend to reduce consumption of non-renewable sources.

On the other hand, Legislative Decree no. 119/2020 amends Legislative Decree no. $209 / 2003$ and strengthens the effectiveness and efficiency of systems tracing and securing end-of-life vehicles and waste deriving from their treatment, with particular reference to the obligation to weigh end-of-life vehicles at an assembly center. Firms in the agrifood sector use tractors and agricultural machinery to operate, and when they intend to dispose of them, they will have to comply with the rules laid down in this respect to ensure sustainable management of the disposal, thereby aligning themselves with sustainable and circular management principles.

\subsection{Legislation on By-Products and End-of-Waste Status within the Circular Economy Package}

Within the national regulatory framework on the circular economy, Legislative Decree 152/2006, the "Environmental Consolidation Act" ("Testo Unico Ambientale") regulates "by-products". This Legislative Decree contains the amendments made by Legislative Decree no. 116/2020.

In the context of agri-food supply chains, Circular Economy Network (CEN) [64] highlights the importance of adopting appropriate and sustainable practices based on the efficient use of resources, reduction of waste and reuse and recycling.

The possibility of using production scraps or processing residues in a production process as raw material, in fact, has a positive impact on the environment, resulting in less waste generation and less need to draw on virgin raw materials, which are replaced by those scraps or residues, if appropriately treated.

Given the variety of supply chains that characterize agri-food production, it is important to be able to define in concrete terms when a production scrap or processing residue can be recognized as a by-product, paying attention to distinguishing this notion from that of end-of-waste status. All this defining process is strictly connected with the waste hierarchy ("Art. 4 Directive 2008/98/EC of the European Parliament and of the Council of 19 November 2008"), as shows Figure 4, specified by article 179, "Priority criteria in waste management", of Legislative Decree no. 152/2006. This rule defines the priority criteria that must guide operators in waste management to pursue the best environmental option [65].

In particular, the waste hierarchy identifies five levels or grades that shall apply as a priority order: (1) prevention; (2) preparing for re-use; (3) recycling; (4) other recovery, e.g., energy recovery; (5) disposal.

Prevention "means measures taken before a substance, material or product has become waste".

Preparing for re-use provides for the possibility of processing a waste in order to use it, and for this purpose, this level or grade includes "checking, cleaning, disassembly and repair operations by which products or components of products that have become waste are prepared so that they can be re-used without any other pre-processing". 
Recycling "includes any recovery operation by which waste materials are reprocessed into products, materials or substances whether for the original or other purposes. It includes the reprocessing of organic material but does not include energy recovery and the reprocessing into materials that are to be used as fuels or for backfilling operations. Particularly 'recovery' means any operation the principal result of which is waste serving a useful purpose by replacing other materials which would otherwise have been used to fulfil a particular function, or waste being prepared to fulfil that function, in the plant or in the wider economy. Annex II sets out a non-exhaustive list of recovery operations".

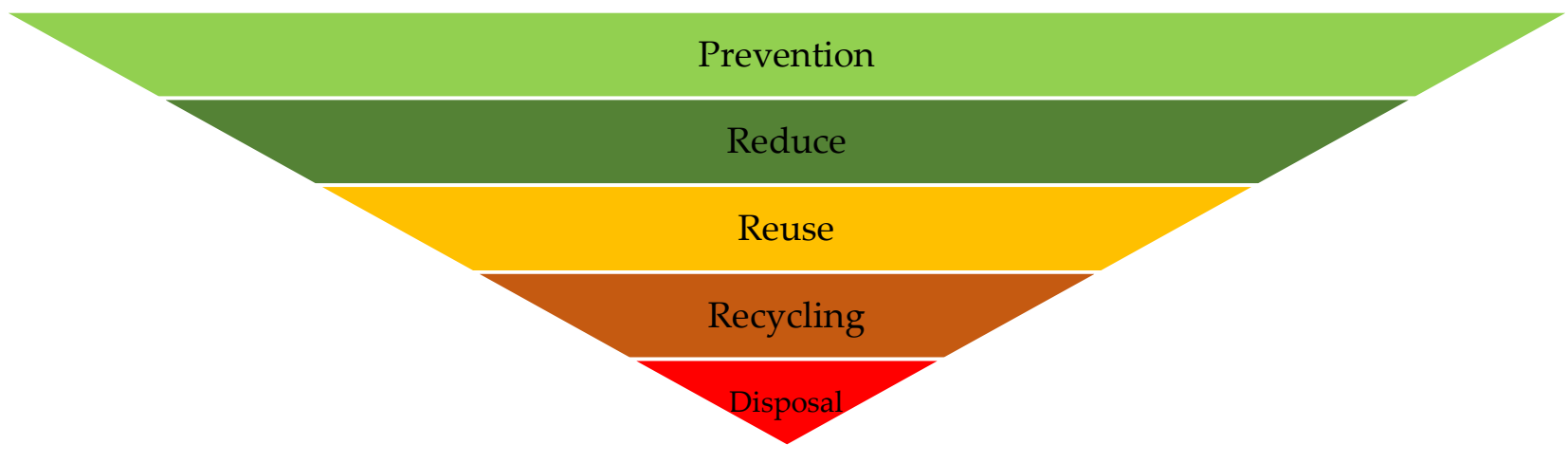

Figure 4. Waste Hierarchy.

Other recovery, e.g., energy recovery includes types of recovery not covered by the preceding definition.

Disposal consists in "any operation, which is not recovery even where the operation has as a secondary consequence the reclamation of substances or energy. Annex I sets out a non-exhaustive list of disposal operations".

By-product and end-of-waste status-despite sharing the same objective to reduce the production of waste and to reintroduce the resulting residues into production cycles whenever possible-widely differ.

What keeps by-products (Art. 184-bis Legislative Decree 152/2006) and the end-ofwaste status (Art. 184-ter Legislative Decree no. 152/2006) distinct is the moment in which they are generated in the waste hierarchy.

Firstly, waste "means any substance or object, which the holder discards or intends or is required to discard".

The by-product is at the first level of the waste hierarchy (prevention) because, although it is a production scrap or a processing residue, it contains characteristics that allow not to classify it as waste and so to use it in a further production process.

By product, in fact, is any scrap or residue of production that meets all the following conditions (Art. 184-bis, point 1 of Legislative Decree no. 152/2006),

"(a) the substance or object originates in a production process, of which it is an integral part, and whose primary purpose is not the production of that substance or object;

(b) further use of the substance or object is certain, in the same or a subsequent production or use process, by the producer or a third party;

(c) the substance or object can be used directly without any further processing other than normal industrial practice;

(d) further use is lawful, i.e., the substance or object fulfils all relevant product, environmental and health protection requirements for the specific use and will not lead to overall adverse environmental or human health impacts."

The choice between using or disposing of the substance or object is the producer's. If the producer wishes to extend the life of the substance or object, it must verify that the scrap production or processing residue comply with all the regulatory constraints required to classify it as a by-product. 
In fact, when the substance or object does not meet all requirements and conditions of the standard, it is not possible to define it as a by-product, but rather as waste. Once classified as waste, the producer must send the substance or object to a landfill and dispose of it.

However, with certain types of disposal, it is not the only option. The waste, in fact, if it is subjected to specific recovery operations, loses this status and acquires a new one and so it is possible to use it as a raw material for a new production process. This is the case with the end-of-waste status. Therefore, in the context of the waste hierarchy, end-of-waste status is at the level/grade of "re-use" (i.e., at the second level) since the waste "ceases to be waste". All this is subject to the conditions above.

Concerning the management of by-products, it is necessary to verify that scrap production or residue processing meets all the requirements set by law. First, it is necessary to ascertain that scrap or residue can be used directly, without any further treatment other than normal industrial practice (as provided for Legislative Decree no. 152/2006, article 184-bis, c). Furthermore, it is required, among other conditions, that it is certain that the substance or product, i.e., scrap or residue, will be used during the same or a subsequent production or use process, by the same producer or third parties (Legislative Decree no. $152 / 2006$, article 184-bis, b). In addition, the "certainty of use" requirement is a peremptory condition; if this condition is not met, the law does not allow qualifying scraps and residues as a by-product and, consequently, it must be considered waste. When the residue results to be waste, the firm that carried out the production process must dispose of it in compliance with the relevant regulations on disposal. It must also bear the related administrative and disposal costs. More precisely, it is mandatory to dispose of the substance or object if it is not intended for a specific use that is lawful; to be lawful, its use must also meet the requirements of the regulations on health and environmental protection so as not to harm the environment or on human health (Legislative Decree no. 152/2006, article 184-bis, d). The specificity of these rules makes clear the importance of proper management of the by-product. As a matter of fact, if a substance or product is potentially qualifiable as by-product, any failure to comply with the exact requirements for the proper use, as examined, would not allow the firm to use it as a raw material for another process, causing loss of many benefits both in economic terms and circularity. In fact, from the use of the by-product, the firm gains an economic advantage: obtains a saving in terms of purchase of production factors, which result replaced by the scrap or residue; it does not incur disposal costs. In an environmental view, by-product use also avoids a negative impact, generating benefits in circular terms, as there is less need for extraction of virgin resources and the creation of potentially polluting waste.

With regard to the end-of waste status, specifically, Legislative Decree no. 152/2006, article 184-ter establishes that

"A waste shall cease to be waste, when it has undergone a recovery operation, including recycling and preparing for re-use, and complies with specific criteria to be developed in accordance with the following conditions:

(a) the substance or object is intended to be used for specific purposes;

(b) a market or demand exists for such a substance or object;

(c) the substance or object meets the technical requirements for the specific purposes and complies with existing regulations and standards applicable to products;

(d) the use of the substance or object will not result in overall adverse environmental or human health impact".

From the above provision, the difference between the by-product and the end-of-waste status is that the former is never classified as waste and allows pursuing the objectives of prevention. The second, on the other hand, is initially categorized as waste and only later, in case the firm that produced has the intention to requalify it, it can be put back into a production cycle as a resource. 
Therefore, given the different nature of by-products and the end-of-waste status, they must be managed differently in practice. The by-product is the required a treatment of normal industrial practice (Legislative Decree no. 152/2006, Article 184-bis, c), reintroducing a waste into a new production process [66], however, it requires a more complex requalification process. The waste requalification process, in fact, requires for firms that deal with it to perform specific operations. Carrying out of these operations, by individuals or firms requires, among other things, a special license issued by a regional administration responsible for the specific area (Legislative Decree no. 152/2006, Article 208). The activity, once authorized [67], is exposed to the control of the Italian Institute for Environmental Protection and Research (ISPRA), within the Italian Network for Environmental Protection (SNPA). ISPRA's method presents some criticalities that suggest normative interventions to modify aspects, both of the bureaucratic process and aspects of the control mode in place, also in the light of the policies on sustainability that address a circular economy.

Unlike by-products, therefore, in order to reuse waste in a new production process, firms face higher charges and costs, both in terms of waste requalification and administration procedures. Instead, in the same way as with by-products, firms benefit both economically and environmentally. They benefit economically in terms of savings in administrative and disposal costs and saving purchasing "virgin resources" cost. Environmental benefits are measurable in terms of circularity resulting from a lower use of virgin resources and a lower level of waste generation.

The transition to a more circular economy, i.e., from a linear to an agroecological transition [68], even though it is not always easy, especially in the case of linear production processes, set up according to a diachronic model "extract, produce, use, throw away" [69], it seems to become increasingly urgent.

The provisions [70] updated by Law no. 128/2019 confirm that it is necessary to conduct the waste recovery operation in compliance with criteria that meet the conditions listed in Art. 184-ter Legislative Decree no. 152/2006.

Where such criteria are lacking, law sets that license for requalification operations shall be issued or renewed by local authorities on a case-by-case basis. This in accordance with the conditions set out in Article 6 of Directive 2008/98/EC and based on detailed criteria established within the permitting procedures. The latter may set, if deemed necessary, other limit values for pollutants taking into account all the possible adverse environmental effects of the substance or object under consideration.

As already pointed out for by-products, as well as for "end-of waste status", if legal requirements to reintroduce the waste, i.e., the substance or product, into a new production cycle are not met it is mandatory to apply all regulations in force regarding disposal. In this case, the enterprise will have to dispose of the waste according with Legislative Decree no. $152 / 2006$ and bear all relative costs. In the opposite hypothesis, when waste ceases to be waste, pursuant to and for the purposes of Art. 183-ter of Legislative Decree no. 152/2006, if requalified by the firm, it would be considered in the calculation of the recovery and recycling objectives established by law, contributing to raising the levels of circularity and lowering those of environmental impact.

The consequences, in case of mismanagement, and therefore of non-compliance with the certain, specific and legal use of a substance or product are severe, determining criminal liability and financial penalties; in this sense, there have already been ascertained legal cases.

\section{The Case Law of Olive Pomace as By-Product}

Olive oil has a large economic relevance in terms of production and consumption [40] in the Mediterranean regions: during the 2019-2020 marketing year, olive oil production amounted to 3.0 million tons, equal to $94 \%$ of total world production [71,72]. In the European Union, the production is of 1.924 thousand tons, equal to $60 \%$ of the world production, while in Italy the production is of 366 thousand tons, ranking behind Spain 
with 1.125 thousand tons; together with Greece they are the main producing countries in the EU $[71,72]$. For this reason, Italy is the second-largest European producer of olive pomace.

Given the importance of the olive oil sector in Italy, within the by-products subject in the agri-food sector, the improper use of olive pomace, i.e., the scrap generated by the production of olive oil, is of some interest. In Italy, the issue has given rise also to a case law that has recently (2019-2020) gone through all the degrees of judgment provided by the Italian justice system $[73,74]$.

The dispute aimed to establish whether an olive oil firm had complied with the regulations on by-products by using olive pomace for agricultural purposes in accordance with the requirements of Art. 184-bis, paragraph 1.1 of Legislative Decree no. 152 of 2006, which would satisfy the "certainty of use" requirement, set by Art. 184-bis l. b. In fact, if in the case the substance or product, i.e., the olive pomace, was not used during the same or a subsequent production or use process, by the same producer or third parties, it would have had to be disposed of in a landfill.

First of all, jurisprudence in the various levels of judgment has verified that olive pomace, being a residual fraction of olive processing (as consisting of pulp and skin), met the condition set by Legislative Decree no. 152 of 2006, Art. 184-bis, paragraph 1, "l. a) the substance or object originates in a production process, of which it is an integral part, and whose primary purpose is not the production of that substance or object". Second, it was ascertained that olive pomace is known for its fertilizing properties, could have been used as a soil conditioner/improver-fertilizer. Therefore, it was potentially possible to use it for agricultural purposes and so to meet the conditions required by Legislative Decree no. 152 of 2006, Art. 184-bis, paragraph 1, "l. b) further use of the substance or object is certain, in the same or a subsequent production or use process, by the producer or a third party". However, the firm involved in the process did not prove the effective use of olive pomace for agricultural purposes. To exploit the soil amendment properties of olive-pomace it is necessary to prepare the land and carry outspreading and incorporation operations, which in fact did not take place. This did not occur, on the contrary, jurisprudence ascertained that in the specific case, the olive pomace had been dumped in an olive grove in a state of abandonment ("the plants being covered with brambles") and that no prior authorization was requested from the municipality. These circumstances determined the jurisprudence to exclude the possibility of inferring that the olive-pomace had been used for agricultural purposes, but rather to dispose of it.

The failure to provide evidence of olive-pomace use as a fertilizer did not make it possible to meet the requirement of certainty of use in "a subsequent production process or use by the producer or third parties", therefore, jurisprudence has excluded the possibility, in this case, to qualify olive pomace as a by-product. Consequently, the miller owner, having failed to conduct proper by-product management [75] of the olive pomace, i.e., to carry out the necessary spreading and incorporation operations to exploit the properties of the by-product, should have disposed of it as waste in compliance with the relevant regulations. The failure to comply with these regulations has led the court to convict the mill, where the production process took place, in the person of its legal representative, guilty of the offence referred to in Legislative Decree no. 152 of 2006, Art. 256, paragraph 2, "Activity of unauthorized waste management".

All of the above demonstrates that in interpretative, jurisprudential terms, the letter of the above-mentioned regulatory discipline as per Art. 184-bis of Legislative Decree no. $152 / 2006$ is confirmed.

According to this legislation, a given substance can be exempted from the waste regime if it is managed according to the by-product rules, as otherwise criminal convictions and fines may apply. Therefore, all operators in the sector must ensure that they use by-products following the law (i.e., not improperly) and are not operating at the legal limit.

In conclusion, the miller had the possibility to valorize the processing residue or scrap that he produced, reusing it in a new production process. Thus, the implementation of this 
circular management model would have yielded economic benefits, but the miller failed to manage the scrap/residue in a proper way.

When this happens, firms should dispose of their process scraps and/or processing residues to not incur criminal liability (Figure 5).

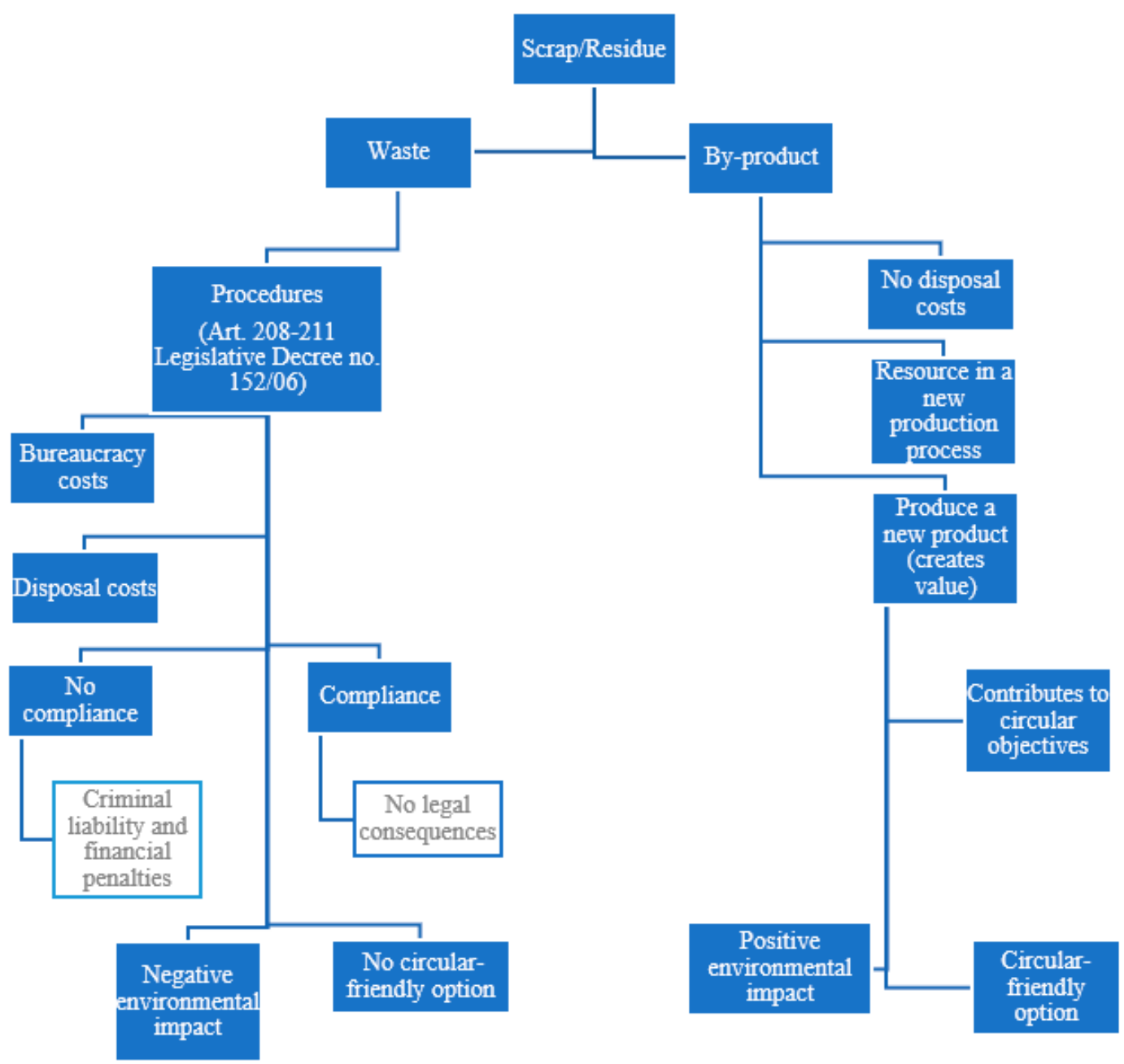

Figure 5. Circular Economy Management Model.

Implementing the valorization of scraps and residues virtuous model would also generate environmental benefits by avoiding increasing the level of waste that is still high fulfilling circular economy's purpose. In fact, in the EU, around 88 million tons of food waste are generated annually with associated costs estimated at 143 billion euros; the quantities of industrial food waste are very significant, ranging from $19 \%$ to $39 \%$ of total food waste in European food supply chains [76,77]. However, only a small amount, i.e., $46 \%$, of wastes is currently recycled in the European countries [78], while a huge percentage of potential secondary raw materials is discharged on landfill. The percentage of recycled waste varies widely across Europe, and in Italy the recycling rate is at $48 \%$ [78].

\section{New Emergencies Context: The European Green Deal}

The strategic path to sustainable growth, the function of the objectives of applying and developing the circular economy paradigm, continues with the Communication "The European Green Deal" [79], presented by the European Commission at the end of 2019, gaining new facets. In fact, the Green Deal's strategy aims to make the EU a climate-neutral, fair and prosperous society, based on an economy that manages resources efficiently and sustainably while ensuring its competitiveness starting with the climate crisis. 
Furthermore, the Circular Economy Network (CEN) [64] identifies the circular economy as an indispensable tool for achieving the environmental objectives of climate neutrality.

As part of the instruments of the European Green Deal, "A new Circular Economy Action Plan For a cleaner and more competitive Europe" [80] proposes initiatives that cover the entire life cycle of products in order to modernize and transform the economy while ensuring environmental protection with respect to the fight against pollution and recycling of waste. To realize this ambition, according to the plan, the EU must do all it can to reduce its consumption footprint and double the percentage of circular materials use in the next decade. The Plan states, in fact, that the EU will continue to play a leading role towards a circular economy that benefits people, regions and cities, that fully contributes to climate neutrality and fully exploits the potential of research, innovation and digitalization. This with the understanding that there is not an exhaustive set of requirements to ensure that all products placed on the EU market gradually become more sustainable and meet circular criteria.

Regarding the agri-food system, within the Green Deal, the strategy "Farm to Fork" [81] is central. This strategy comprehensively addresses the challenges of achieving sustainable agri-food systems by recognizing the inextricable links between healthy people, healthy societies and a healthy planet [81]. The orientation is to think in an integrated way when planning agricultural, food and forestry policy may lead to green and inclusive solutions in response to the main support needs of the ecological transition.

Thus, combating food loss and waste reduction contributes to the achievement of sustainability of food resources; however, this relates not only to waste management, waste reduction, but also to feed production, food safety, biodiversity, the bio-economy, and renewable energy. The bio-economy, in particular, offers opportunities to promote sustainable and socially responsible production methods and circular business models in the food processing and retail sectors [81]. In terms of renewable energy, farms have the potential to implement a regenerative management system through the exploitation of by-product and end-of-waste status and to produce biogas from other sources of waste and residues [82] (such as the food and drink industry, black water, wastewater and municipal waste).

Farm to Fork Strategy within EU Green Deal expresses how it is necessary to leave behind the vision of isolated segments of the agri-food production system to embrace the one that covers all the stages of the food chain intended as a chain of links from farms, including workers, to the consumer.

The agri-food production system showed great resilience during the pandemic and so it may play a fundamental role in the relaunch of the Country.

While the European institutions were striving to boost sustainable growth, the world was preparing to face a global crisis. The unexpected change induced by the COVID19 pandemic that has spread, causing economic and social damage [83]; the attempt to repair the consequences required the European institutions to review their policy priorities. The question then arose as to whether reprogramming would in any way result in the elimination of circularity as a priority, thus bringing to a halt the path generated and outlined by the Green Deal.

This has not happened and, on the contrary, the European Union states that, in pursuing the aim of getting out of the crisis that has arisen, the foundations must be laid for a more modern and sustainable Europe. The European Union, therefore, makes the role of the Green Deal central, confirming its fundamental importance in achieving the circular economy's objectives in the new context.

Given the extraordinary need to finance the economic recovery of the EU Member States hit by the COVID-19 crisis, the European Commission, with its Communication "The EU budget powering the Recovery Plan for Europe" [84] proposes the introduction of an emergency European recovery instrument: the "Next Generation EU" (NGEU) [15]. Next Generation EU consists mainly of two support instruments for Member States "REACTEU" [85] and the Recovery and Resilience Facility (RRF) [86] but its total funds amount is of 
EUR 750 billion [87]. The general objective is to promote the economic, social and territorial cohesion of the Union by improving the resilience and adjustment capacity of Member States, mitigating the social and economic impact of the crisis and supporting green and digital transitions. Thus, the intent is to contribute to restoring the growth potential of Union economies by stimulating job creation in the aftermath of the COVID-19 crisis within the framework of sustainable growth.

In order to benefit from the European resources, each Member State must submit to the European Commission a National Recovery and Resilience Plan (NRRP) outlining investment and reform plans consistent with the European program lines. Beside the need of coherence at a national level, the Commission states (Communication, 2021/C 58/01) [88] that no measure included in a national "Recovery and Resilience Plan" (RRP) shall be detrimental to environmental objectives.

Italy submitted its NRRP (14) at the end of April 2021. It has provided the following six ad hoc 'missions' that reflect NGEU six 'pillars' ideology of the Regulation (EU) 2021/241 (RFF) [86]. Among the Italian NRRP missions, the "Green revolution and ecological transition" is the most connected to the agri-food sector. It incorporates the objectives of the European Green Deal where a focus on "Sustainable agriculture and circular economy" is guaranteed.

The fact that the pandemic has not led to a loss of political, economic and financial support under the European Green Deal, and the Plan and the Strategy connected to it, is a further confirmation of the centrality of the issues surrounding the circular economy paradigm. In fact, the conclusions of the extraordinary meeting of the European Council (17-21 July 2020) [87] state that the Program for the Environment and Climate Action, LIFE, will provide support for the conservation of biodiversity and the transformation of the Union into a clean, circular, energy-efficient, low-carbon and climate-resilient society.

In this respect, the CEN 2021 report argues that if each stage of the production process were carried out according to the principles of the circular economy, agriculture, livestock farming, and land use could concretely contribute to cutting greenhouse gas emissions by $7.2 \mathrm{GtCO}_{2}$ eq per year, or up to $20 \%$ of the emission reductions needed by 2050 [64].

\section{Discussions, Implications and Further Research}

From a study of the main documents of the European institutions on the circular economy and of those implementing them in Italy, it emerged that specific regulatory instruments are lacking in the agri-food sector.

In our opinion, this circumstance creates uncertainty, and considering that the byproduct and end-of-waste status's management requires strict adherence to the regulations in force, and that deviation from them implies criminal liability, we believe that urgent actions are needed by the relevant institutions in order to overcome information asymmetry and incompleteness that can create distortions at various levels.

Specific regulatory measures of circular economy for the agri-food sector would also facilitate operators of any level of activity, to be able to make choices that give rise to the implementation of circular production. These, among other things, can contribute to the environmental and social balances as established by the EU for each production sector in question.

However, it is relevant to highlight that, recently, the EU has shown attention to the agri-food sector with the Farm to Fork strategy as part of the European Green Deal. Similarly, in Italy, the National Recovery and Resilience Plan seems to represent an attempt to make circularity interventions specific to the agri-food sector, particularly in the context of the "component" indicated as "Sustainable Agriculture and Circular Economy".

It would be desirable, for this tendency, which takes into account the specific characteristics of the different segments of the agri-food production chains, to become increasingly predominant and to be institutionalized on a regulatory level.

In light of the above, we believe that future research may directed some efforts towards giving voice to the lack of specific regulatory references on the circular economy with reference to the agro-food sector, as well as in order to stimulate regulatory interventions 
in this direction. In fact, there are many issues involved in this sector, and the by-products of the specific olive oil sector were chosen not only because it is one of the most important productive segments in Italy, but also as a representative one. This does not exclude other supply chains, but rather it would be significant to replicate this study focusing on some, in order to verify whether the considerations reached in this research would be confirmed in one or more segments that characterize the various production chains of the sector under examination.

\section{Conclusions}

This paper proposes an analysis of European planning instruments and related implementation provisions in Italy, aimed at framing, without any claim to being exhaustive, measures on the circular economy and verifying their relative effectiveness in the agri-food sector. The study found a programmatic context that is substantially coherent and favorable to the implementation of policies that aim at environmental sustainability.

At the same time, shortcomings have emerged in policy interventions in the agri-food sector that led to a lack of clarity and affect its efficiency. The multiplicity of economic activities that characterize this sector, suffering from the lack of targeted legislative guidelines, is unable to fully grasp the opportunities offered by policies to encourage measures aimed at implementing circularity, although in the agri-food sector, different supply chains these could find ample room for application throughout the relevant phases.

Each agri-food chain generates within its phases (agricultural production, processing and distribution) production residues and/or scraps and wastes of different nature and in changing quantities, from which new production factors may arise implementing the regulatory measures on by-product and end-of-waste status, as referred to in the paper. Pursuing this regenerative model would lead firms [89-91] to a reduction in waste disposal costs; in this way, enterprises in the agri-food sector would participate also in the containment of greenhouse gas emissions and, consequently, they would contribute to the fight against climate change, sustainability and the environment.

It is hoped that the indications of this work would contribute to stimulate more space for direct interventions for the agri-food sector in the context of the current phase of preparation of EU policy and normative documents. First and foremost, the European Green Deal is underway with the aim to mobilize investment for the green economy and achieve climate neutrality by 2050. These strategies find financial support in NextGenerationEu (NGEU) and in the more recent National Recovery and Resilience Plan (NRRP). Also of relevance is the recent Regulation (EU) 2020/852 [92] of the European Parliament and of the Council of 18 June 2020 on the establishment of a framework to facilitate sustainable investment, which makes it clear that an economic activity may and should make a substantial contribution to waste prevention, re-use and recycling.

In this context, it should be noted that the EU has strengthened the role of environmental policies through circularity interventions and, while these are still not specific to the agri-food sector, the Farm to Fork strategy is directly oriented towards this sector as part of the European Green Deal.

These EU programmatic initiatives have not decelerated due to the COVID-19 health emergency; on the contrary, they have been strengthened and adapted to support the serious ongoing pandemic event. In fact, in order to repair the immediate economic and social damages caused by the coronavirus pandemic, the goal of creating a post-COVID-19 Europe that is more resilient, green, digital and adapted to present and future challenges has become even more urgent.

It is hoped that along the agri-food chain, firms will undertake to comply with the regulatory instruments to meet the circular objectives, as well as the principles and provisions on climate and the environment. Compliance with this is also a prerequisite for intercepting the financial resources made available by the European Union in order to make the transition to a circular economy, despite the economic crisis. 
In light of the considerations expressed, in our opinion, it appears that the interpretation of the political measures is not simple and the knowledge regarding the support instruments is not so widespread among agri-food business operators. In this sense, it is our expectation that the present work may also have provided elements to support interpretation of the regulatory and institutional measures of reference.

Author Contributions: Conceptualization, C.Z., G.C. and M.D.; methodology, C.Z. and G.C.; investigation, B.P., C.Z. and S.B.; resources, M.D. and G.C.; data curation, C.Z.; writing-original draft preparation, C.Z., G.C., G.L.V., B.P., S.B. and M.D.; writing-review and editing, C.Z. and G.C.; supervision, G.C. and M.D.; funding acquisition, M.D. and G.C. All authors have read and agreed to the published version of the manuscript.

Funding: This research received a grant from the Project PRIN DRASTIC “Driving The Italian AgriFood System Into A Circular Economy Model," PRIN-MIUR (2017 JYRZFF), funded by the Italian Ministry of Education, University and Research (MIUR), and project MODESTI by Starting Grant "PIAno di inCEntivi per la RIcerca di Ateneo 2020/2022 (Pia.ce.ri.)" UNICT (5A722192150).

Institutional Review Board Statement: Not applicable.

Informed Consent Statement: Not applicable.

Data Availability Statement: Not applicable.

Acknowledgments: The authors would like to thank Luigi Cembalo, Principal Investigator of the Project PRIN 2017-DRASTIC, for reading the first draft of the paper and providing useful suggestions for its improvement. The authors are solely responsible for the content of the paper.

Conflicts of Interest: The authors declare no conflict of interest.

\section{References}

1. Ghisellini, P.; Cialani, C.; Ulgiati, S. A review on circular economy: The expected transition to a balanced interplay of environmental and economic systems. J. Clean. Prod. 2016, 114, 11-32. [CrossRef]

2. Filho, J.A.D.L.; Vieira, R.J.; de Souza, C.A.; Ferreira, F.F.; de Oliveira, V.M. Effects of habitat fragmentation on biodiversity patterns of ecosystems with resource competition. Phys. A Stat. Mech. Appl. 2021, 564, 125497. [CrossRef]

3. Greyson, J. An economic instrument for zero waste, economic growth and sustainability. J. Clean. Prod. 2007, 15, 1382-1390. [CrossRef]

4. Marco-Fondevila, M.; Llena-Macarulla, F.; Callao-Gastón, S.; Jarne-Jarne, J. Are circular economy policies actually reaching organizations? Evidence from the largest Spanish companies. J. Clean. Prod. 2021, 285, 124858. [CrossRef]

5. World Economic Forum (WEF). Harnessing the Fourth Industrial Revolution for Water-Fourth Industrial Revolution for the Earth Series. 2018. Available online: https://espas.secure.europarl.europa.eu/orbis/sites/default/files/generated/document/ en/WEF_WR129_Harnessing_4IR_Water_Online.pdf (accessed on 16 June 2021).

6. Galli, A.; Pires, S.M.; Iha, K.; Alves, A.A.; Lin, D.; Mancini, M.S.; Teles, F. Sustainable food transition in Portugal: Assessing the footprint of dietary choices and gaps in national and local food policies. Sci. Total Environ. 2020, 749, 141307. [CrossRef] [PubMed]

7. Artuzo, F.D.; Allegretti, G.; Santos, O.I.B.; da Silva, L.X.; Talamini, E. Energy unsustainability index for agricultural systems assessment: A proposal based on the laws of thermodynamics. Sci. Total Environ. 2021, 759, 143524. [CrossRef] [PubMed]

8. Brunori, C. Un'agenzia tecnica per chiudere il cerchio. Ecoscienza 2019, 5, 14-15.

9. Zarbà, C.; La Via, G.; Pappalardo, G.; Hamam, M.S. The sustainability of novel foods in the transition phase to the circular economy; The trade "algae fit for human consumption" in European Union. AIMS Agric. Food Open Access 2020, 5, 54-75.

10. Leoni, S. Le performance italiane, un bilancio in chiaroscuro. Ecoscienza 2019, 5, 12-13.

11. Bratti, A. Il collegato ambientale, una legge organica per la green economy. Ecoscienza 2015, 6, 34-39.

12. Massarutto, A. L'economia circolare conviene? Ecoscienza 2019, 5.

13. Dell'Anno, B.; Grassi, L.; Iannotti, M. Economia circolare e sostenibilità per 1'Italia. Ecoscienza 2019, 5.

14. McDowall, W.; Geng, Y.-J.; Huang, B.; Barteková, E.; Bleischwitz, R.; Türkeli, S.; Kemp, R.; Doménech, T. Circular economy policies in China and Europe. J. Ind. Ecol. 2017, 21, 651-661. [CrossRef]

15. European Commission. Recovery Plan for Europe. 2021. Available online: https://ec.europa.eu/info/strategy/recovery-planeurope_en (accessed on 8 June 2021).

16. Presidenza del Consiglio dei Ministri. Trasmissione del PNRR al Parlamento. 2021. Available online: https:/ /www.governo.it/ sites/governo.it/files/PNRR_0.pdf (accessed on 30 May 2021).

17. Cecchetti, M. Note introduttive allo studio delle normative tecniche nel sistema delle fonti a tutela dell'ambiente. In Osservatorio sulle Fonti; De Siervo, U., Ed.; Giappichelli: Torino, Italy, 1996; pp. 145-165. 
18. Şanta, A.-M.I. The energy union-Perspectives for consolidating the European Union through a common energy market. Manag. Mark. Chall. Knowl. Soc. 2019, 14, 232-239. [CrossRef]

19. Lähteenmäki-Uutela, A.; Grmelová, N. European law on insects in food and feed. Eur. Food Feed. Law Rev. 2016, 11, 2-8.

20. Lähteenmäki-Uutela, A.; Grmelová, N.; Hénault-Ethier, L.; Deschamps, M.-H.; Vandenberg, G.W.; Zhao, A.; Zang, Y.; Yang, B.; Nemane, V. Insects as food and feed: Laws of the European Union, United States, Canada, Mexico, Australia, and China. Eur. Food Feed. Law Rev. 2017, 12, 22-36.

21. Murray, A.; Skene, K.; Haynes, K. The circular economy: An interdisciplinary exploration of the concept and application in a global context. J. Bus. Ethic 2015, 140, 369-380. [CrossRef]

22. Toni, F. I Fondamenti Dell'Economia Circolare. 2015. Available online: http://www.comitatoscientifico.org/temi\%20 SD/documents/Green\%20economy/FEDERICO\%20Appunti\%20di\%20economia\%20circolare\%20250315.pdf (accessed on 12 May 2021).

23. Boulding, K.E. The economics of the coming spaceship earth. In Environmental Quality in a Growing Economy; Jarrett, H., Ed.; Johns Hopkins University Press: Baltimore, MD, USA, 1966; pp. 3-14.

24. Cardoso, J.L. The circular economy: Historical grounds. In Changing Societies: Legacies and Challenges. The Diverse Worlds of Sustainability; Delicado, A., Domingos, N., de Sousa, L., Eds.; Imprensa de Ciências Sociais: Lisbon, Portugal, 2018; Volume 3, pp. 115-127.

25. Turner, K.; Pearce, D.; Bateman, I. Environmental Economics. An Elementary Introduction; The Johns Hopkins, University Press: Baltimore, MD, USA, 1993.

26. Turner, R.K. Environmental economics. Environ. Geol. 1999. [CrossRef]

27. Lyle, J.T. Regenerative Design for Sustainable Development; John Wiley and Sons: New York, NY, USA, 1966 ; ISBN 9780471178439.

28. Commoner, B. The Closing Circle: Nature, Man and Technology; Dover Publications: Mineola, NY, USA, 2020.

29. Stahel, W.R.; Reday-Mulvey, G. Jobs for Tomorrow. The Potential for Substituting Manpower for Energy; Vantage Press: New York, NY, USA, 1981.

30. Peiró, L.T.; Polverini, D.; Ardente, F.; Mathieux, F. Advances towards circular economy policies in the EU: The new ecodesign regulation of enterprise servers. Resour. Conserv. Recycl. 2020, 154, 104426. [CrossRef]

31. Ayres, R.U. Industrial metabolism. In Technology and Environment; Ausubel, J., Sladovich, H.E., Eds.; National Academy Press: Washington, DC, USA, 1989.

32. Frosch, R.A.; Gallopoulos, N.E. Strategies for manufacturing. Sci. Am. 1989, 261, 144-152. [CrossRef]

33. Turner, R.K.; Pearce, D.W. The Ethical Foundations of Sustainable Economic Development; London Environmental Economics Centre/International Institute for Environment and Development: London, UK, 1990.

34. Turner, R.K.; Pearce, D.W. Sustainable economic development: Economic and ethical principles. In Economics and Ecology; Barbier, E.B., Ed.; Springer: Dordrecht, Germany, 1993.

35. Mhatre, P.; Panchal, R.; Singh, A.; Bibyan, S. A systematic literature review on the circular economy initiatives in the European Union. Sustain. Prod. Consum. 2021, 26, 187-202. [CrossRef]

36. Pauli, G. Blue Economy. Nuovo Rapporto al Club di Roma. 10 Anni, 100 Innovazioni, 100 Milioni di Posti di Lavoro; Edizioni Ambiente: Milano, Italy, 2010.

37. Thibaut, W. The concept of circular economy: Its origins and its evolution. Work. Pap. 2018. [CrossRef]

38. Andersen, M.S. An introductory note on the environmental economics of the circular economy. Sustain. Sci. 2006, 2, 133-140. [CrossRef]

39. Su, B.; Heshmati, A.; Geng, Y.; Yu, X. A review of the circular economy in China: Moving from rhetoric to implementation. J. Clean. Prod. 2013, 42, 215-227. [CrossRef]

40. Ellen MacArthur Foundation. Delivering the Circular Economy: A Toolkit for Policymakers. 2015. Available online: https: / / www.ellenmacarthurfoundation.org/publications / delivering-the-circular-economy-a-toolkit-for-policymakers (accessed on 16 June 2021).

41. Kirchherr, J.; Reike, D.; Hekkert, M. Conceptualizing the circular economy: An analysis of 114 definitions. Resour. Conserv. Recycl. 2017, 127, 221-232. [CrossRef]

42. De Römph, T.J.; Cramer, J.M. How to improve the EU legal framework in view of the circular economy. J. Energy Nat. Resour. Law 2020, 38, 1-16. [CrossRef]

43. Kullmann, F.; Markewitz, P.; Stolten, D.; Robinius, M. Combining the worlds of energy systems and material flow analysis: A review. Energy Sustain. Soc. 2021, 11, 13. [CrossRef]

44. Abokersh, M.H.; Norouzi, M.; Boer, D.; Cabeza, L.F.; Casa, G.; Prieto, C.; Jimenez, L.; Valles, M. A framework for sustainable evaluation of thermal energy storage in circular economy. Renew. Energy 2021, 175, 686-701. [CrossRef]

45. Borrello, M.; Pascucci, S.; Cembalo, L. Three propositions to unify circular economy research: A review. Sustainability 2020, 12, 4069. [CrossRef]

46. Borrello, M.; Pascucci, S.; Caracciolo, F.; Lombardi, A.; Cembalo, L. Consumers are willing to participate in circular business models: A practice theory perspective to food provisioning. J. Clean. Prod. 2020, 259, 121013. [CrossRef]

47. Raimondo, M.; Caracciolo, F.; Cembalo, L.; Chinnici, G.; Pappalardo, G.; D'Amico, M. Moving towards circular bioeconomy: Managing olive cake supply chain through contracts. Sustain. Prod. Consum. 2021, 28, 180-191. [CrossRef] 
48. Hamam, M.; Chinnici, G.; Di Vita, G.; Pappalardo, G.; Pecorino, B.; Maesano, G.; D’Amico, M. Circular economy models in agro-food systems: A review. Sustainability 2021, 13, 3453. [CrossRef]

49. Panchal, R.; Singh, A.; Diwan, H. Does circular economy performance lead to sustainable development? A systematic literature review. J. Environ. Manag. 2021, 293, 112811. [CrossRef]

50. Hartley, K.; van Santen, R.; Kirchherr, J. Policies for transitioning towards a circular economy: Expectations from the European Union (EU). Resour. Conserv. Recycl. 2020, 155, 104634. [CrossRef]

51. European Commission. Communication from the Commission to the European Parliament, the Council, the European Eco-nomic and Social Committee and the Committee of the Regions. A Resource-Efficient Europe-Flagship Initiative under the Europe, COM (2011). 2020. Available online: https://www.eea.europa.eu/policy-documents/a-resource-efficient-europe-flagship (accessed on 8 June 2021).

52. European Commission. Communication from the Commission to the European Parliament, the Council, The European Eco-nomic and Social Committee and the Committee of the Regions. Towards a Circular Economy: A Zero Waste Programme for Europe, COM/2014/398. 2014. Available online: https://eur-lex.europa.eu/legal-content/EN/TXT/?uri=celex\%3A52014DC0398 (accessed on 8 June 2021).

53. European Commission. Communication from the Commission to the European Parliament, the Council, The European Economic and Social Committee and the Committee of the Regions. Closing the Loop-An EU Action Plan for the Circular Economy, COM (2015). 2015. Available online: https:/ / eur-lex.europa.eu/legal-content/EN/TXT/?uri=CELEX\%3A52015DC0614 (accessed on 15 February 2015).

54. Zarbà, C.; Chinnici, G.; Pecorino, B.; D'Amico, M.; Bracco, S. The European Union responses to the impact of COVID-19 on SMEs in the Italian agri-food system. In Proceedings of the International Multidisciplinary Scientific GeoConference Surveying Geology and Mining Ecology Management (SGEM), Vienna, Austria, 8-11 December 2020; pp. 161-168.

55. Turco, G. Economia circolare: Definizione e politiche europee. Ius Itinere. 2020. Available online: https://www.iusinitinere.it/ economia-circolare-definizione-e-politiche-europee-33885 (accessed on 22 December 2020).

56. Gregori, G. Con la bioeconomia focus su territori e risorse. Ecoscienza 2019, 5.

57. Svensson-Hoglund, S.; Richter, J.L.; Maitre-Ekern, E.; Russell, J.D.; Pihlajarinne, T.; Dalhammar, C. Barriers, enablers and market governance: A review of the policy landscape for repair of consumer electronics in the EU and the U.S. J. Clean. Prod. 2021, 288, 125488. [CrossRef]

58. Massarutto, A. Rapporto della Commissione Europea sull'attuazione del piano d'azione per l'economia circolare. Ecoscienza 2019, 5 .

59. Hughes, R. The EU circular economy package—Life cycle thinking to life cycle law? Procedia CIRP 2017, 61, 10-16. [CrossRef]

60. Belliggiano, A.; Conti, M. L'agroecologia come formula di sostenibilità e recupero dei saperi locali. In Perspectives on Rural Development. Despoblación y Transformaciones Sociodemográficas de los Territorios Rurales: Los Casos de España, Italia y Francia; Cejudo, E., Navarro, F., Eds.; Università del Salento: Lecce, Italy, 2019; Volume 3.

61. Boeraeve, F.; Dendoncker, N.; Cornélis, J.-T.; Degrune, F.; Dufrêne, M. Contribution of agroecological farming systems to the delivery of ecosystem services. J. Environ. Manag. 2020, 260, 109576. [CrossRef]

62. Ameli, M.; Mansour, S.; Ahmadi-Javid, A. A simulation-optimization model for sustainable product design and efficient end-of-life management based on individual producer responsibility. Resour. Conserv. Recycl. 2019, 140, 246-258. [CrossRef]

63. Friant, M.C.; Vermeulen, W.J.; Salomone, R. Analysing European Union circular economy policies: Words versus actions. Sustain. Prod. Consum. 2021, 27, 337-353. [CrossRef]

64. Circular Economy Network. Rapporto sull'Economia Circolare in Italia-2021. Focus sull'Economia Circolare nella Transizione alla Neutralità Climatica. Fondazione per lo Sviluppo Sostenibile. 2021. Available online: https: / circulareconomynetwork.it/ wp-content/uploads/2021/03/3\%C2\%B0-Rapporto-economia-circolare_CEN.pdf (accessed on 16 June 2021).

65. Stankevičius, A.; Novikovas, A.; Bakaveckas, A.; Petryshyn, O. EU waste regulation in the context of the circular economy: Peculiarities of interaction. Entrep. Sustain. Issues 2020, 8, 533-545. [CrossRef]

66. Singhal, D.; Tripathy, S.; Jena, S. Remanufacturing for the circular economy: Study and evaluation of critical factors. Resour. Conserv. Recycl. 2020, 156, 104681. [CrossRef]

67. Ravazzolo, M. Il ruolo dell'industria e il primato italiano nella UE. Ecoscienza 2019, 5.

68. Quendler, E.; Ikerd, J.; Driouech, N. Family farming between its past and potential future with the focus on multifunctionality and sustainability. CAB Rev. 2020, 15. [CrossRef]

69. Ferrara, R. Brown economy, green economy, blue economy: L'economia circolare e il diritto dell'ambiente. Piemonte Auton. 2018, 2 .

70. Bortone, G.; Fantini, G. End of waste, luci e ombre della recente riforma. Ecoscienza 2019, 5.

71. Consiglio per la Ricerca in Agricoltura e L'Analisi Dell'Economia Agraria (CREA). Annuario Dell'Agricoltura Italiana 2019; Consiglio per la Ricerca in Agricoltura e L'Analisi Dell'Economia Agraria (CREA): Roma, Italy, 2021.

72. International Olive Council. Economic Affairs and Promotion Unit. 2021. Available online: https://www.internationaloliveoil. org/what-we-do/economic-affairs-promotion-unit/ (accessed on 29 June 2021).

73. Ministero della Giustizia. Tribunale di Savona, Sentenza del 14/05/2019; Savona. 2019. Available online: https://www. tuttoambiente.it/sentenze-premium/rifiuti/?s_item=8b313cbf30999888de32da1ec83ff503 (accessed on 1 June 2021). 
74. Corte Suprema di Cassazione. Cassazione Penale, Sez. III, Ud. 30-01-2020, Sent. 06-03-2020, n. 9056. 2020. Available online: https://montanambiente.com/wp-content/uploads/2020/04/Sentenza-n.-9056-del-6_03_2020.pdf (accessed on 1 June 2021).

75. Iglesias, E.; de Miguel, E.O. Present and future of wastewater reuse in Spain. Desalination 2008, 218, 105-119. [CrossRef]

76. Garske, B.; Heyl, K.; Ekardt, F.; Weber, L.M.; Gradzka, W. Challenges of food waste governance: An assessment of European legislation on food waste and recommendations for improvement by economic instruments. Land 2020, 9, 231. [CrossRef]

77. Stenmarck, Å.; Jensen, C.; Quested, T.; Moates, G.; Cseh, B.; Juul, S.; Parry, A.; Politano, A.; Redlingshofer, B.; Scherhaufer, S.; et al. Estimates of European Food Waste Levels; Fushions: Stockholm, Sweden, 2016; ISBN 9789188319012.

78. European Environment Agency. Waste Recycling. 2019. Available online: https://www.eea.europa.eu/data-and-maps/ indicators/waste-recycling-1 (accessed on 16 April 2021).

79. European Commission. Communication from the Commission to the European Parliament, the Council, the European Eco-nomic and Social Committee and the Committee of the Regions. The European Green Deal, COM(2019). 2019. Available online: https:/ / ec.europa.eu/info/publications/communication-european-green-deal_en (accessed on 11 December 2019).

80. European Commission. Communication from the Commission to the European Parliament, the Council, the European Eco-nomic and Social Committee and the Committee of the Regions. A New Circular Economy Action Plan For a Cleaner and More Competitive Europe, COM/(2020)/98 Final. 2020. Available online: https://eur-lex.europa.eu/legal-content/EN/TXT/?uri= CELEX\%3A52020DC0098 (accessed on 11 March 2020).

81. European Commission. Communication from the Commission to the European Parliament, the Council, The European Eco-nomic and Social Committee and the Committee of the Regions. A Farm to Fork Strategy for a Fair, Healthy and Environmental-LyFriendly Food System, COM/2020/381 Final. 2020. Available online: https:// eur-lex.europa.eu/legal-content/EN/TXT/?uri= CELEX\%3A52020DC0381 (accessed on 20 May 2020).

82. Recchia, L.; Cini, E.; Corsi, S. Multicriteria analysis to evaluate the energetic reuse of riparian vegetation. Appl. Energy 2010, 87, 310-319. [CrossRef]

83. Di Marco, L. Obiettivi di Sviluppo Sostenibile e Politiche Europee. 2020. Available online: https://asvis.it/public/asvis2/files/ Pubblicazioni/Quaderno_Obiettivi_di_sviluppo_sostenibile_e_politiche_europee.pdf (accessed on 16 June 2021).

84. European Commission. Communication from the Commission to the European Parliament, the Council, The European Eco-nomic and Social Committee and the Committee of the Regions. The EU Budget Powering the Recovery Plan for Europe COM(2020) 442 Final. 2020. Available online: https:/ / eur-lex.europa.eu/legal-content/EN/TXT/?uri=COM\%3A2020\%3A442\%3AFIN (accessed on 27 May 2020).

85. Regulation (EU) 2020/2221 of the European Parliament and of the Council of 23 December 2020 Amending Regulation (EU) No 1303/2013 as Regards Additional Resources and Implementing Arrangements to Provide Assistance for Fostering Crisis Repair in the Context of the COVID-19 Pandemic and its Social Consequences and for Preparing a Green, Digital and Resilient Recovery of the Economy (REACT-EU). Available online: https:/ / eur-lex.europa.eu/legal-content/EN/TXT/?uri=CELEX\%3A32020R2221 (accessed on 23 December 2020).

86. Regulation (EU) 2021/241 of the European Parliament and of the Council of 12 February 2021 Establishing the Recovery and Resilience Facility. Available online: https:/ / eur-lex.europa.eu/legal-content/EN/TXT/?uri=CELEX\%3A32021R0241 (accessed on 12 February 2021).

87. European Council. Special Meeting of the European Council (17-21 July 2020)—Conclusions. 2020. Available online: https: / / www.consilium.europa.eu/media/45109/210720-euco-final-conclusions-en.pdf (accessed on 13 September 2020).

88. European Commission. Commission Notice Technical Guidance on the Application of "Do No Significant Harm" under the Re-covery and Resilience Facility Regulation 2021/C 58/01. 2021. Available online: https:/ / eur-lex.europa.eu/legal-content/ EN/TXT/?qid=1616413015984\&uri=CELEX\%3A52021XC0218\%2801\%29 (accessed on 8 June 2021).

89. Zarbà, C.; Chinnici, G.; Pecorino, B.; D'Amico, M. Paradigm of the circular economy in agriculture: The case of vegetable seedlings for transplantation in nursery farms. In Proceedings of the International Multidisciplinary Scientific GeoConference Surveying Geology and Mining Ecology Management (SGEM), Vienna, Austria, 9-11 December 2019; pp. 113-120.

90. Chinnici, G.; Zarbà, C.; Hamam, M.; Pecorino, B.; D’Amico, M. A model of circular economy of citrus industry. In Proceedings of the International Multidisciplinary Scientific GeoConference Surveying Geology and Mining Ecology Management (SGEM), Vienna, Austria, 9-11 December 2019; pp. 19-26.

91. Pascucci, S. Circular food economies. In Routledge Handbook of Sustainable and Regenerative Food Systems, 1st ed.; Duncan, J., Carolan, M., Wiskerke, J.S.C., Eds.; Routledge Taylor \& Francis Group: Abingdon, UK, 2020; pp. 318-335.

92. Regulation (EU) 2020/852 of the European Parliament and of the Council of 18 June 2020 on the establishment of a framework to facilitate sustainable investment and amending Regulation (EU) 2019/2088. Available online: https:/ / eur-lex.europa.eu/legalcontent/EN/TXT/?uri=celex:32020R0852 (accessed on 22 June 2020). 